\title{
Impacts of Climate Change on Agriculture and Food Security Issues in Malaysia: An Empirical Study on Farm Level Assessment
}

\author{
Md. Mahmudul Alam * \\ Institute for Environment and Development (LESTARI) \\ National University of Malaysia (UKM), Malaysia; \\ E-mail: rony000@ gmail.com \\ Chamhuri Siwar \\ Institute for Environment and Development (LESTARI) \\ National University of Malaysia (UKM), Malaysia \\ E-mail: csiwar@ukm.my \\ Md. Wahid Murad \\ Business School, Faculty of the Professions \\ The University of Adelaide, Australia \\ E-mail: wahid.murad@adelaide.edu.au \\ Mohd Ekhwan bin Toriman \\ School of Social, Development \& Environmental Studies \\ Faculty of Social Sciences and Humanities (FSSK) \\ National University of Malaysia (UKM), Malaysia \\ E-mail: ikhwan@ukm.my \\ * Corresponding Author
}

\section{Citation Reference:}

Alam, M.M., Siwar, C., Murad, M.W., and Mohd Ekhwan, T. 2011. Impacts of Climate Change on Agriculture and Food Security Issues in Malaysia: An Empirical Study on Farm Level Assessment, World Applied Sciences Journal, Vol. 14(3), pp. 431-442. Available at < www.idosi.org/wasj/wasj14(3)11/12.pdf > (ISSN 1818-4952; PublisherInternational Digital Organization for Scientific Information)

This is a pre-publication copy.

The published article is copyrighted by the publisher of the journal. 


\title{
Impacts of Climate Change on Agriculture and Food Security Issues in Malaysia: An Empirical Study on Farm Level Assessment
}

\begin{abstract}
Climate change is proven to have had impacted the agricultural productivity, crop choice, and food security everywhere in the world. The nature, scale, frequency, and outcome of such impact differ significantly among countries, regions and areas within a country. This study is an effort to empirically investigate theses issues for Malaysia using both primary and secondary data collected from and relevant to the Integrated Agriculture Development Areas in the Northwest Selangor. The results reveal that climate change phenomenon such as natural disaster, drought, flood, pest attack, plant disease, and changing the time of crop cycle have adversely been impacting Malaysian agriculture and its productivity as well as profitability. Despite continuous increases of government subsidy as well as permission only for paddy production, the paddy planting area is decreasing as the agricultural farmers often experience adverse impacts of climatic variation. So, climate change phenomenon is also depressingly impacting the state of food security among the farmers. As climate change is universal and its existence is indefinite, the farmers need to adapt to and find ways to mitigate the damages of climatic variation in order for them to sustain agricultural productivity and attain food security.
\end{abstract}

Key words: Climate Change, Agricultural Productivity, Crop Choice, Food Security, Paddy Farming, Farm Profitability, Agricultural Sustainability, Malaysia.

\section{INTRODUCTION}

Agriculture is primarily and heavily dependent on climate. The uncontrollable natures of climate factors, such as temperature, rainfall, soil moisture, flood, drought, other natural disaster etc., are changing over the time affecting agricultural, economic, social, and environmental sustainability. Due to the climate change, several agricultural factors, such as yield, cultivated area, and value of crops, are changing that influences the sustainability of agriculture. Changes in climate affect the productivity of different crops differently. Therefore, changes in outputs and economic returns from different crops differ significantly 
affecting the decision of crop selection. Climate change also affects the state of food security at both household and national levels.

In fact, climate change has mixed impacts on agriculture. The global impacts of climate change on agricultural production vary from slight to moderate, while the regional impacts are observed to be significant in many areas. Regional variations in gains and losses result in a slight overall changes in world food productivity. Several studies suggest that climate change will slow or reverse the rural poverty increasing the negative impacts on agriculture. Warren et al. mentioned that some 600 million additional people are at risk of hunger if temperature increases by over $3^{\circ} \mathrm{C}^{[1]}$ Climate change may slow the rates of improvement in food security. Projection by a study reveals that in 2080 around 1300 million people could be at risk of hunger under the most extreme scenarios, that is around 600 million more than that in 1999. ${ }^{[2]}$ The Food and Agriculture Organization (FAO) reports that over 860 million people in the world are suffering from severe food insecurity and chronic malnourishment, and about 95 percent of them are in developing countries. ${ }^{[3]}$

The Intergovernmental Panel on Climate Change (IPCC) mentioned Africa as one of the most vulnerable continents to climate change. ${ }^{[4]}$ Very few parts of Africa will be benefited from a rising temperature, unlike some parts of the northern hemisphere. The United Nations Framework Convention on Climate Change (UNFCCC) identifies a list of 49 Least Developed Countries (LDCs), which are at high risk from climate change and 33 of these countries are located in Africa. A study revealed that due to climate change, Southern Africa will lose more than $30 \%$ of its main crop, maize, by 2030, and Asia, especially South Asia and South East Asia will lose top $10 \%$ of many regional staples, such as rice, millet and maize. $^{[5]}$

Studies also have linked the climate change impacts to the yield variation of cash crops, such as rice, wheat, and tobacco, in South and Southeast Asian regions. ${ }^{[6-7]}$ Climatic impacts on agriculture span a wide range of attributes and outcomes depending on the specific climate scenario, geographical location, and nature of study. For example, while major climate changes were predicted for China, to a certain extent warming would be beneficial for yield increasing in the country due to diversification of cropping systems. In case of Japan, the positive effects of $\mathrm{CO}_{2}$ on rice yields would generally more than offset any negative climatic effects. ${ }^{[8]}$ But in case of Malaysia, under current climate change scenario, 
temperature above $25^{\circ} \mathrm{C}$ may decline grain mass of $4.4 \%$ per $1^{\circ} \mathrm{C}$ rise ${ }^{[9]}$, and grain yield may decline as much as $9.6 \%-10.0 \%$ per $1^{\circ} \mathrm{C}$ rise ${ }^{[10]}$, whereas an average temperature in rice growing areas in Malaysia is about $26^{\circ} \mathrm{C}$. Singh et al. revealed that the actual farm yields of rice in Malaysia vary from 3-5 tons per hectare, where potential yield is 7.2 tons. ${ }^{[1]}$ The study also revealed that there is a decline in rice yield between $4.6 \%-6.1 \%$ per $1{ }^{\circ} \mathrm{C}$ temperature increase and that doubling of $\mathrm{CO}_{2}$ concentration (from present level 340ppm to $680 \mathrm{ppm}$ ) may offset the detrimental effect of $4^{\circ} \mathrm{C}$ temperature increase on rice production in Malaysia. Overall, based on the analysis of minimum and maximum yield of last 28 years, the macro cases of the national data from 1980 to 2008 of Malaysia shows the yield of paddy would be decreased between $43 \%$ and $61 \%$ if $1{ }^{\circ} \mathrm{C}$ temperature and 1 millimeter $(\mathrm{mm})$ rainfall increased. ${ }^{[12]}$ In a recent study, based on the micro data on paddy field of Integrated Agricultural Development Area (IADA), North-West Selangor, it has been found that a $1 \%$ increase in temperature will lead to $3.44 \%$ decrease in current paddy yield and $0.03 \%$ decrease in paddy yield in next season. Also a $1 \%$ increase in rainfall will lead to $0.12 \%$ decrease in current paddy yield and $0.21 \%$ decrease of paddy yield in next season. ${ }^{[13]}$

However, the climatic factors are changing very rapidly in Malaysia. According to the United Nations Development Report, carbon dioxide $\left(\mathrm{CO}_{2}\right)$ emissions in Malaysia increased by $221 \%$ during the period from 1990 to 2004 and the country has been placed in the list of 30 biggest greenhouse gas emitters in the world. ${ }^{[14]}$ Liebman also revealed that rapid growth in $\mathrm{CO}_{2}$ emissions has been occurred even though Malaysia ratified the Kyoto Protocol and has taken several initiatives to use renewable energy as well as ways to cut emissions. ${ }^{[15]}$ Currently Malaysia ranks as the 26th largest greenhouse gas emitter in the world with a population of about 27 million, and it appears likely to move up the list quickly due to the growth rate of emissions. Due to high greenhouse gas emissions, the average temperature is projected to rise by $0.3^{\circ} \mathrm{C}$ to $4.5^{\circ} \mathrm{C}$ and the warmer temperature will cause a rise in sea level about $95 \mathrm{~cm}$ over hundred periods. The changes in rainfall may fluctuate from about $-30 \%$ to $+30 \%$. This change will reduce crop yield and is prone to drought in many areas so that cultivation of some crops such as rubber, oil palm and cocoa will not be possible. ${ }^{[8]}$

Moreover, the recent projection shows maximum monthly precipitation, which will increase up to $51 \%$ over Pahang, Kelantan and Terengganu, while minimum precipitation decreases between $32 \%$ and $61 \%$ for all over Peninsular Malaysia. Consequently, annual rainfall will increase up to $10 \%$ in Kelantan, Terengganu, Pahang and North West Coast, and 
decrease up to $5 \%$ in Selangor and Johor. ${ }^{[16]}$ Tisdell found that rainfall variability increases the level of environmental stress that affects the capability of the system to maintain productivity. ${ }^{[17]}$ Projection reveals that any changes, both positive and negative, more than only $0.4 \%$ will cause to fall the yield of paddy production in Malaysia. ${ }^{[8]}$ Alam et al. found that total yearly rainfall in Malaysia is increasing but its monthly variation is too high. In Malaysia, the effect of lower rainfall is almost possible to check through proper irrigation system, but the opposite phenomenon of over rainfall for any particular time, especially at the end of the crop cycle or at the maturity period, causes serious damages of crops, which is absolutely uncontrollable for now. ${ }^{[18]}$

In order to sustain the self-sufficiency level and food security of the nation through increasing food productivity, income, and the provision of improved irrigation and drainage facilities and other complementary inputs, such as fertilizers, pesticides, and weedicides etc, and other agricultural services such as extension, credit, marketing and subsidies, the Integrated Agricultural Development Projects (IADPs) were adopted since 1971 in Malaysia. When initiated, however, there were eight IADPs in Malaysia and they have then been renamed as IADAs.

\section{Contribution of Agriculture to National Economy and Food Security}

In the path of economic development from agriculture to industrial movement, the agricultural sector of Malaysia has been declining its share of GDP since 1975. In 1970, the contribution of agriculture to GDP was $30.8 \%$ which is the highest among all sectoral contribution. The contribution of the agriculture to the GDP accounted $22.7 \%$ in $1975,22.9 \%$ in 1980 and $20.8 \%$ in 1985, but it was still the major contributor in GDP. In 1990, agriculture became the second largest sector contributing $18.7 \%$ to the national GDP. In 1995, the contribution of agriculture to the national GDP further declined to $13.6 \%$, but it remained as the second largest sector in the economy. The contribution of the sector continued to decline to $8.9 \%$ in 2000 and $8.2 \%$ in 2005 . While the agriculture sector was loosing its importance to the national economy, services and manufacturing sectors have taken the first and second highest contributing roles respectively, placing the agriculture as the third engine of economic growth in the country (Table 1).

Table 1: Sectoral Contribution to GDP (in \%) in Malaysia. ${ }^{[19-23]}$ 


\begin{tabular}{|c|c|c|c|c|c|c|c|c|}
\hline \multirow{2}{*}{ Industry } & \multicolumn{8}{|c|}{ Year } \\
\hline & 1970 & 1975 & 1980 & 1985 & 1990 & 1995 & 2000 & 2005 \\
\hline $\begin{array}{l}\text { Agriculture, livestock, forestry } \\
\text { \& fishery }\end{array}$ & 30.8 & 22.7 & 22.9 & 20.8 & 18.7 & 13.6 & 8.9 & 8.2 \\
\hline Mining \& quarry & 6.3 & 4.6 & 10.1 & 9.7 & 5.7 & 7.4 & 7.3 & 6.7 \\
\hline Manufacturing & 13.4 & 16.4 & 19.6 & 19.7 & 27.0 & 33.1 & 31.9 & 31.4 \\
\hline Construction & 3.9 & 3.8 & 4.6 & 4.8 & 3.5 & 4.4 & 3.3 & 2.7 \\
\hline Services (total) & 41.9 & 45.1 & 40.1 & 43.6 & 42.3 & 44.1 & 53.9 & 58.1 \\
\hline Electric, gas \& water & 1.9 & 2.1 & 1.4 & 1.7 & 1.9 & 2.3 & 3.9 & 4.1 \\
\hline $\begin{array}{l}\text { Transportation, storage \& } \\
\text { communication }\end{array}$ & 4.7 & 6.2 & 5.7 & 6.4 & 6.9 & 7.3 & 8.0 & 8.8 \\
\hline Wholesale, trade, retail & 13.4 & 12.8 & 12.8 & 12.1 & 11.0 & 12.1 & 14.8 & 14.7 \\
\hline $\begin{array}{l}\text { Finance, insurance \& } \\
\text { properties }\end{array}$ & 8.4 & 8.5 & 8.5 & 8.9 & 9.7 & 10.7 & 12.7 & 15.1 \\
\hline Government services & 11.1 & 12.7 & 12.7 & 12.2 & 10.7 & 9.7 & 6.8 & 7.6 \\
\hline Other services & 2.5 & 2.8 & 2.8 & 2.3 & 2.1 & 2.0 & 7.6 & 7.8 \\
\hline
\end{tabular}

Use of land by Malaysia's agriculture also continues to decrease due to the country's rapid economic development, which occupies more agricultural land mainly for housing, business, and industrial purposes. Since 1960 until 2005, the land use for industrial crops is increasing while it is decreasing for food crops (Table 2). It just means that the major part of agricultural land is being used for growing industrial crops and that importance of growing food crops continues to decrease. In 1960, for example, land use for food crops accounted for $31.5 \%$ of the total agricultural land in Malaysia while it has decreased to $16.3 \%$ in 2005 . Among the industrial crops, palm oil sector accounted for the largest share of the total land utilization in the country. Agricultural land use by the palm oil sector has significantly increased over the last five decades with only $2.1 \%$ in 1960 to $63.4 \%$ in 2005 . This just reveals the facts that palm oil production has been getting more importance and contributing significantly to the national economy.

Table 2: Distribution of Agricultural Land Utilization (in \%) in Malaysia. ${ }^{[19-23]}$

\begin{tabular}{lcccccccccc}
\hline \multirow{2}{*}{ Crop } & \multicolumn{10}{c}{ Year } \\
\cline { 2 - 11 } & 1960 & 1965 & 1970 & 1975 & 1980 & 1985 & 1990 & 1995 & 2000 & 2005 \\
\hline Industrial crops(Total) & 68.5 & 71.7 & 68.0 & 69.3 & 71.7 & 76.1 & 81.3 & 77 & 80.2 & 83.7 \\
Rubber & 65.7 & 66.9 & 58.6 & 51.2 & 45.1 & 39.3 & 44 & 30.6 & 26.1 & 19.6 \\
Palm Oil & 2.1 & 4.0 & 8.4 & 16.5 & 23 & 29.9 & 30.4 & 37.9 & 48.8 & 63.4 \\
Cocoa & 0.0 & 0.1 & 0.2 & 0.7 & 2.8 & 6.1 & 6.3 & 7.9 & 4.7 & 0.5 \\
Pineapple & 0.6 & 0.6 & 0.6 & 0.5 & 0.3 & 0.2 & 0.1 & 0.2 & 0.3 & 0.1 \\
Tobacco & 0.1 & 0.1 & 0.1 & 0.3 & 0.3 & 0.3 & 0.2 & 0.2 & 0.2 & 0.2 \\
\hline Food Crops (Total) & 31.5 & 28.3 & 32.0 & 30.7 & 26.8 & 22.6 & 17.9 & 21.7 & 18.8 & 16.3 \\
Paddy & 17.5 & 16.8 & 20.8 & 19.5 & 16.5 & 13.1 & 10 & 11.3 & 7.5 & 7.1 \\
Coconut & 9.2 & 8.1 & 8.7 & 7.4 & 7.9 & 6.7 & 4.7 & 5.7 & 4.1 & 2.8 \\
Vegetables & 1.3 & 0.7 & 0.5 & 0.3 & 0.3 & 0.3 & 0.5 & 0.3 & 0.8 & 1 \\
Fruits & 1.5 & 1.6 & 1.6 & 1.7 & 2.1 & 2.4 & 2.7 & 4.3 & 6.4 & 5.2 \\
Others & 1.9 & 1.1 & 0.4 & 1.9 & 1.5 & 1.4 & 0.9 & 1.3 & 1 & 0.3 \\
\hline
\end{tabular}


In Malaysia, there is no specific policy on food security, but it has been embedded into the theme of self sufficiency level that referred to paddy or rice sector. ${ }^{[24]}$ Since rice is the main staple food in Malaysia, self-sufficiency level has been focused on paddy and rice production. However, the scope has been expanded to other food items including fruits, vegetables, fish products, beef, mutton, pork, chicken, duck, eggs, and dairy products in the First National Agriculture Plan in 1984. To ensure food security in Malaysia, however, government follows two procedures, such as establishing self-sufficiency level and maintaining rice stocks both domestically and internationally. Malaysia has had never met food self-sufficiency level. About $10 \%$ to $35 \%$ of total required rice imported from neighboring countries, such as Thailand, Vietnam, Myanmar, India, and Pakistan. The highest food self-sufficiency level for the country was $95 \%$ and the lowest one was $65 \%$, which were recorded in 1975 and 1990, respectively. National Paddy and Rice Board (LPNlater been privatized as Padiberas Nasional Berhad - BERNAS) is the authorized body to manage the domestic rice stock.

Table 3: Recent Paddy Statistics in Malaysia. ${ }^{[25]}$

\begin{tabular}{lrrrrrr}
\hline \multicolumn{1}{c}{ Item } & 2003 & 2004 & 2005 & 2006 & 2007 & $2008^{\mathrm{P}}$ \\
\hline Paddy Parcels Area (Hectare) & 459,702 & 459,044 & 440,961 & 429,805 & 426,224 & 426,260 \\
Average Yield of Paddy (Kg./Ha.) & 3,360 & 3,434 & 3,471 & 3,236 & 3,514 & 3,556 \\
Paddy Production ('000 Tones) & 2,257 & 2,291 & 2,314 & 2,187 & 2,375 & 2,384 \\
Rice Production ('000 Tones) & 1,453 & 1,467 & 1,490 & 1,407 & 1,531 & 1,535 \\
Production Values (RM’000) & $1,241,350$ & $1,260,050$ & $1,272,700$ & $1,421,550$ & $1,543,750$ & $1,788,000$ \\
Total Rice Import ('000 Tones) & 398.7 & 558.1 & 584.7 & $843.3^{\mathrm{P}}$ & $798.7^{\mathrm{P}}$ & $657.9^{\mathrm{P}(1)}$ \\
\hline
\end{tabular}

${ }^{1}$ For Jan -Jun $2008 ;{ }^{2} \mathrm{~A}$ paddy parcel is a piece of land which is usually used for paddy planting

The current record shows a positive trend of import and a negative trend of land usage for paddy production in Malaysia (Table 3). The objectives of government's policy about paddy and rice sector reflect three issues: ensure sufficient supply and affordable price for the citizens, meet the target of self sufficiency level, and ensure high prices to paddy farmers for better income and reducing higher level of poverty in this sector. ${ }^{[24,26,27]}$

\section{SOURCES OF DATA AND SAMPLE DESIGN}


In order to determine and analyze the impacts of climate change on agricultural productivity, crop choice, and food security, primary data have been collected through an in depth survey on farmers in the IADA area of North-West Selangor, Malaysia. The total agricultural land in the above IADA area is 100,000 hectares, where 55,000 hectares are being cultivated for palm oil, 20,000 hectares for coconut, 5,000 hectares for fruits and vegetable, and 20,000 hectares for paddy. The 20,000 hectares allocated for paddy also consist of river, drain, and road. Within the 20,000 hectares allocated for paddy farming, the total paddy producible area is actually 18,638 hectares, but paddy is currently being planted within 18,355 hectares and the rest 283 hectares of land are currently unused. Moreover, total paddy irrigated area is 18,980 hectares, where an extra 625 hectares are being used for irrigation drainage. The IADA area in Northwest Selangor further consists of eight areas where total reported paddy farmers are about 10,300, other crop producing farmers are about 30,000, and the total size of the agricultural community reported in the area is about 50,000.

Among the paddy producing farmers, a total of 198 farmers were interviewed using a structured questionnaire under a research project entitled "The economics of climate change: Economic dimensions of climate change, impacts and adaptation practices in agriculture sector: Case of paddy sector in Malaysia”, conducted by the Institute for Environment and Development (LESTARI) of the National University of Malaysia (UKM) funded by Ministry of Science, Technology and Environment of the Government of Malaysia. ${ }^{[28]}$ Data for this project were collected through a sample survey of paddy producing farmers in the eight sections of the Integrated Agricultural Development Area (IADA) of North-West Selangor, Malaysia. Trained enumerators were hired to interview the respondents in all IADA areas using a stratified-quota random sampling technique. All the 198 agricultural farmers interviewed in the study were reported to have been cultivating a total 577.53 hectares of land for paddy production. Details socioeconomic profiles of the respondents are available at Alam and others. ${ }^{[29-30]}$

Relevant secondary data have also been collected from several sources, such as IADA publication, Ministry of Science Technology and the Environment (MOSTE) publication, National Hydraulic Research Institute of Malaysia (NAHRIM) publication, Agriculture Statistical Handbook, and Government of Malaysia various fifth-year plans.

\section{RESULTS AND DISCUSSION}




\section{Impacts of Climatic Change on Crop Productivity}

Available literatures have revealed earlier that climate change has an adverse impact on agriculture in Malaysia. The projection of paddy yield in the country showed that any positive or negative variation of above $0.4 \%$ in both rainfall and temperature will decrease the yield of paddy production by 2020 (Table 4). When considering a positive or negative variation of above $0.7 \%$ in both rainfall and temperature by 2040 , paddy yield tends to decline further and this negative trend of paddy yield is expected to continue by the year 2060 , considering the variation $( \pm)$ of above $1 \%$. These clearly indicate a very high level of vulnerability of paddy productivity to the climatic variation in the next couple of decades.

Table 4: Projection of Paddy Yield (Kg/Ha) with Different Variations of Temperature and Rainfall at Certain Level of $\mathrm{CO}_{2} \cdot{ }^{[8]}$

\begin{tabular}{|c|c|c|c|c|c|c|c|c|c|c|c|}
\hline \multicolumn{4}{|c|}{ Year 2020* } & \multicolumn{4}{|c|}{ Year $2040^{\wedge}$} & \multicolumn{4}{|c|}{ Year 2060 } \\
\hline \multirow{2}{*}{$\begin{array}{l}\text { Variation } \\
\text { in } \\
\text { Rainfall }\end{array}$} & \multicolumn{3}{|c|}{$\begin{array}{c}\text { Variation in } \\
\text { Temperature }\left({ }^{0} \mathrm{C}\right)\end{array}$} & \multirow{2}{*}{$\begin{array}{l}\text { Variation } \\
\text { in } \\
\text { Rainfall }\end{array}$} & \multicolumn{3}{|c|}{$\begin{array}{c}\text { Variation in } \\
\text { Temperature }\left({ }^{0} \mathrm{C}\right)\end{array}$} & \multirow{2}{*}{$\begin{array}{l}\text { Variation } \\
\text { in } \\
\text { Rainfall }\end{array}$} & \multicolumn{3}{|c|}{$\begin{array}{c}\text { Variation in } \\
\text { Temperature }\left({ }^{0} \mathrm{C}\right)\end{array}$} \\
\hline & 0.3 & 0.85 & 1.4 & & 0.4 & 1.4 & 2.4 & & 0.6 & 2 & 3.4 \\
\hline $14 \%$ & 6,156 & 5,806 & 5,586 & $23 \%$ & 7,342 & 6,942 & 6,542 & $32 \%$ & 8,619 & 8,059 & 7,499 \\
\hline $7 \%$ & 6,646 & 6,306 & 6,086 & $11 \%$ & 8,200 & 7,800 & 7,400 & $15 \%$ & 9,834 & 9,274 & 8,714 \\
\hline $0.4 \%$ & 7,202 & 6,862 & 6,642 & $0.7 \%$ & 9,042 & 8,642 & 8,242 & $1 \%$ & 10,962 & 10,402 & 9,842 \\
\hline $0 \%$ & 7,202 & 6,862 & 6,642 & $0 \%$ & 9,042 & 8,642 & 8,242 & $0 \%$ & 10,962 & 10,402 & 9,642 \\
\hline $0.4 \%$ & 7,202 & 6,862 & 6,642 & $-0.7 \%$ & 9,042 & 8,642 & 8,242 & $-1 \%$ & 10,962 & 10,402 & 9,642 \\
\hline$-7 \%$ & 6,698 & 6,382 & 6,177 & $-11 \%$ & 8,047 & 7,691 & 7,335 & $-15 \%$ & 9,318 & 8,842 & 8,366 \\
\hline$-14 \%$ & 6,194 & 5,901 & 5,712 & $-23 \%$ & 6,962 & 6,654 & 6,346 & $-32 \%$ & 7,454 & 7,073 & 6,693 \\
\hline
\end{tabular}

$*, \wedge, \sim$ indicates $\mathrm{CO}_{2}(\mathrm{ppm})$ level at 400,600 , and 800 respectively

But the farmers have different views concerning the impacts of climate change on agricultural output. While they were asked about the possible impacts of climate change on paddy yield, $21.2 \%$ indicated that climate change causes productivity to decline (Table 5). There were several reasons that farmers perceived as causing productivity decline in agriculture. For example, $48 \%$ farmers indicated that natural disaster, drought, pest attack, and plant disease negatively affect the crop productivity and hence changes the time of crop cycle. On the other hand, $30.8 \%$ farmers indicated that increase in agricultural input cost does indirectly affect the crop productivity. These farmers have further indicated that the higher input cost results in lesser amount of input use, which eventually causes crop productivity to decline. 
Table 5: Farmers' Perception toward the Effect of the Climate Change on Paddy Production.

\begin{tabular}{lcc}
\hline Response & No. of Respondent & $\%$ of Total \\
\hline \hline Productivity Decline & 42 & $21.20 \%$ \\
Increase Production Cost & 61 & $30.80 \%$ \\
Natural Disaster & 13 & $6.60 \%$ \\
Drought & 10 & $5.10 \%$ \\
Pest Attack & 23 & $11.60 \%$ \\
Plant Diseases & 38 & $19.20 \%$ \\
Timing of Cultivation & 11 & $5.60 \%$ \\
\hline Total & 198 & $100 \%$ \\
\hline
\end{tabular}

All the farmers interviewed were also asked whether or not climatic variation in the IADA area affects their paddy production. A total of $64 \%$ farmers indicated that they have had experienced reduced amount of paddy production due to climatic variation in the area. When the same farmers were asked if climatic variation does also affect the yield of other crops, a majority of those farmers $(65.2 \%)$ responded positively by agreeing that yield of other crops also decreases due to climate changes. Given the fact that climate change negatively affects the yield of paddy and other crops, those farmers were then asked which crop they want to select under such adverse situation. Their response, however, was not in favor of paddy crop as only $23.7 \%$ farmers have chosen this crop followed by $19.7 \%$ farmers who like to produce only short term or seasonal plants, which are not considerably affected by the climatic variation in that particular area. Among those farmers who were asked which crop to select under such adverse climatic situation, as many as $39.4 \%$ farmers have responded that they prefer to cultivate long term plants such as mango, palm oil, coconut, and banana in areas which were actually allocated by the IADA authorities for paddy farming.

\section{Impacts of Climatic Change on Farms' Profitability and Relevant Government Subsidy}

The farmers are dependent on agriculture for their income. As a result, when the quantity of agricultural production declines the income of the farmers also declines, resulting in a loss of their profitability. ${ }^{[31-33]}$ The recent projection by the Ministry of Science, Technology, and the Environment (MOSTE), Malaysia reveals that income earnings from paddy cultivation under different variations of temperature and rainfall are different. For example, any positive or negative variation of above $0.4 \%$ in rainfall will decrease farmers' income earning as well as profitability from paddy production in the next several decades (Table 6). 
Table 6: Projection of Revenue Changes (RM/Ha) for Paddy Production with Variations of Temperature and Rainfall at Certain Level of $\mathrm{CO}_{2} \cdot{ }^{[8]}$

\begin{tabular}{|c|c|c|c|c|c|c|c|c|c|c|c|}
\hline \multicolumn{4}{|c|}{ Year 2020* } & \multicolumn{4}{|c|}{ Year $2040^{\wedge}$} & \multicolumn{4}{|c|}{ Year 2060 } \\
\hline \multirow{2}{*}{$\begin{array}{l}\text { Variation } \\
\text { in } \\
\text { Rainfall }\end{array}$} & \multicolumn{3}{|c|}{$\begin{array}{c}\text { Variation in } \\
\text { Temperature }\left({ }^{0} \mathrm{C}\right)\end{array}$} & \multirow{2}{*}{$\begin{array}{l}\text { Variation } \\
\text { in } \\
\text { Rainfall }\end{array}$} & \multicolumn{3}{|c|}{$\begin{array}{c}\text { Variation in Temperature } \\
\left({ }^{0} \mathrm{C}\right)\end{array}$} & \multirow{2}{*}{$\begin{array}{l}\text { Variation } \\
\text { in } \\
\text { Rainfall }\end{array}$} & \multicolumn{3}{|c|}{$\begin{array}{c}\text { Variation in Temperature } \\
\left({ }^{0} \mathrm{C}\right)\end{array}$} \\
\hline & 0.3 & 0.85 & 1.4 & & 0.4 & 1.4 & 2.4 & & 0.6 & 2 & 3.4 \\
\hline $14 \%$ & -554.2 & -554.2 & -554.2 & $23 \%$ & -892.1 & -892.1 & -892.1 & $32 \%$ & $-1,229.5$ & $-1,229.5$ & $-1,229.5$ \\
\hline $7 \%$ & -291.8 & -291.8 & -291.8 & $11 \%$ & -441.9 & -441.9 & -441.9 & $15 \%$ & -591.9 & -591.9 & -591.9 \\
\hline $0.4 \%$ & 0 & 0 & 0 & $0.7 \%$ & 0 & 0 & 0 & $1 \%$ & 0 & 0 & 0 \\
\hline $0 \%$ & 0 & 0 & 0 & $0 \%$ & 0 & 0 & 0 & $0 \%$ & 0 & 0 & 0 \\
\hline $0.4 \%$ & 0 & 0 & 0 & $-0.7 \%$ & 0 & 0 & 0 & $-1 \%$ & 0 & 0 & 0 \\
\hline$-7 \%$ & -264.5 & -251.9 & -224.0 & $-11 \%$ & -522.1 & -499.1 & -476.0 & $-15 \%$ & -862.7 & -818.6 & -774.5 \\
\hline$-14 \%$ & -529.0 & -504.3 & -488.0 & $-23 \%$ & $-1,091.5$ & $-1,043.2$ & -994.9 & $-32 \%$ & $-1,840.8$ & $-1,764.9$ & $-1,652.4$ \\
\hline
\end{tabular}

$*, \wedge, \sim$ indicates $\mathrm{CO}_{2}(\mathrm{ppm})$ level at 400,600 , and 800 respectively

Note: Revenue calculated as paddy price per 100kg Super Grade= RM55.00 \& Normal Grade= RM51.69

In fact, profitability is an important factor which affects farmers' crop selection. While selecting crops, $37.9 \%$ farmers' decision criteria are based on the profit that includes high return, government subsidy, and high turnover (Table 7). Also 38.4\% farmers indicated that they consider their skills and less requirement of effort to cultivate and manage the crops. Data also reveal that $6.6 \%$ farmers select crops based on their fascination about the crop.

Table 7: Farmers' Crop Selection by Free of Choice and Reasons for Selecting a Particular Crop.

\begin{tabular}{|c|c|c|c|c|c|c|c|c|c|}
\hline \multirow[b]{2}{*}{$\begin{array}{l}\text { Crops } \\
\text { Choice }\end{array}$} & \multicolumn{7}{|c|}{ Reason of Choice } & \multirow{2}{*}{$\begin{array}{c}\text { Total } \\
\text { Respondent }\end{array}$} & \multirow[b]{2}{*}{$\begin{array}{l}\% \text { of total } \\
\text { Respondent }\end{array}$} \\
\hline & $\begin{array}{l}\text { High } \\
\text { Return }\end{array}$ & $\begin{array}{c}\text { Government } \\
\text { Subsidy }\end{array}$ & $\begin{array}{c}\text { High } \\
\text { Turnover }\end{array}$ & $\begin{array}{c}\text { Skilled } \\
\text { Area }\end{array}$ & $\begin{array}{l}\text { Easy to } \\
\text { Manage }\end{array}$ & $\begin{array}{c}\text { High } \\
\text { Passionate }\end{array}$ & NR & & \\
\hline$\overline{\text { Paddy }}$ & 9 & 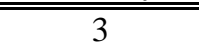 & $\overline{77}$ & 13 & 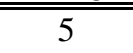 & 10 & & 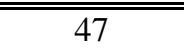 & $23.70 \%$ \\
\hline $\begin{array}{l}\text { Seasonal } \\
\text { Fruits }\end{array}$ & 4 & & 1 & & 3 & 1 & & 9 & $4.50 \%$ \\
\hline Vegetable & 1 & & 5 & & 5 & 1 & & 12 & $6.10 \%$ \\
\hline $\begin{array}{l}\text { Lemon } \\
\text { Grass }\end{array}$ & 1 & & 2 & 1 & 4 & & & 8 & $4.00 \%$ \\
\hline Maize & 2 & & 2 & & 3 & & & 7 & $3.50 \%$ \\
\hline Flower & & & & & 1 & & & 1 & $0.50 \%$ \\
\hline Fishery & & & & & & 1 & & 1 & $0.50 \%$ \\
\hline Lemon & & & & & 1 & & & 1 & $0.50 \%$ \\
\hline Palm Oil & 5 & & 20 & 2 & 20 & & & 47 & $23.70 \%$ \\
\hline Banana & 7 & & 3 & & 9 & & & 19 & $9.60 \%$ \\
\hline Coconut & 1 & & & & 8 & & & 9 & $4.50 \%$ \\
\hline Mango & & & 2 & & & & & 2 & $1.00 \%$ \\
\hline Wood Tree & & & & & 1 & & & 1 & $0.50 \%$ \\
\hline NR & & & & & & & 34 & 34 & $17.20 \%$ \\
\hline Total & 30 & 3 & 42 & 16 & 60 & 13 & 34 & 198 & $100.00 \%$ \\
\hline $\begin{array}{l}\% \text { of } \\
\text { Total }\end{array}$ & $15.20 \%$ & $1.50 \%$ & $21.20 \%$ & $8.10 \%$ & $30.30 \%$ & $6.60 \%$ & $17.2 \%$ & $100 \%$ & \\
\hline
\end{tabular}


Worth noting to mention that government of Malaysia currently provides huge amount of subsidy to the paddy producers to encourage paddy cultivation and to ensure more production for increasing the country's self-sufficiency level. However, the types and contents of these subsidies have been summarized below:

- Input subsidy: 12 beg (20 kg each) compound fertilizer and 4 beg (20kg each) urea fertilizer per hectare - worth MYR 400 and pesticide incentive MYR 200 per hectare.

- Price Subsidy: Provided at the selling price - MYR 248.1 per ton.

- Rice Production Incentive: Land preparation/plowing incentive - MYR 100 per hectare and organic fertilizer 100kg per hectare - worth MYR 140.

- Yield Increase Incentive: Provided if producers (farmers) are able to produce 10 tons or more per hectare - MYR 650 per ton.

- Free Supports: Free supports for irrigation, infrastructure, and water supply.

Table 8: Government Subsidy (in MYR) for Paddy Sector in Malaysia. ${ }^{\text {[25] }}$

\begin{tabular}{lcccr}
\hline \multicolumn{1}{c}{ Items } & 2004 & 2005 & 2006 & \multicolumn{1}{c}{2007} \\
\hline \hline Subsidy For Paddy Price & $476,628,303$ & $443,218,042$ & $445,749,898$ & $444,000,000$ \\
Paddy Fertilizers & $186,744,867$ & $178,072,073$ & $396,393,001$ & $261,677,743$ \\
Paddy Production Incentive & NA & NA & NA & $67,563,904$ \\
Yield Increase Incentive & NA & NA & NA & $85,434,620$ \\
Paddy Seed Help & NA & NA & NA & $17,000,000$ \\
Diesel Subsidy Scheme & NA & NA & $989,727,418$ & $1,099,000,723$ \\
Petrol & NA & NA & $45,413,959$ & $69,461,384$ \\
\hline Total Subsidy and Incentive & $663,373,170$ & $621,290,115$ & $1,877,284,276$ & $2,044,138,374$ \\
\hline
\end{tabular}

Note: NA for data which were not found available.

In order to support the farmers and increase productivity as well as increase income of farmers, government's subsidy for agricultural sector is increasing each year (Table 8). The subsidies for urea and compound fertilizer have been continuing since 1979. The incentive for land preparation and using organic fertilizer has been continuing since 2007. Providing urea and compound fertilizer and pesticide incentive was introduced in 2008 and these supports are still continuing. ${ }^{[34-35]}$

\section{Impacts of Climatic Change on Crop Choice and Farmers' Income}

The government of Malaysia had allocated the IADA area only for paddy production, but paddy production in the area currently provides $90.3 \%$ of agriculture related income to the farmers. About one third of those farmers engaged in IADA area also have income from 
permanent plant such as, mango, coconut, palm oil, cocoa, banana, etc. This is really alarming because the IADA fields are no more being cultivated only for paddy production. Even though the IADA officials have been checking and trying to remove these permanent plants from the fields, but farmers' tendency and attitude are not favorable. The cultivation of these permanent plants, however, provides $7 \%$ of agricultural income to all surveyed farmers as a whole, but a maximum of $63.7 \%$ of agricultural income is also found for an individual case.

Beside producing paddy in the IADA fields, farmers also like to produce seasonal crops, seasonal fruits, and seasonal vegetables. A total of $3 \%$ farmers produce these crops and a maximum of $7.6 \%$ of agricultural income comes from such production of non-paddy crops. Livestock production has also been found as a small source of total agricultural income of paddy producing farmers. Only 6.6\% farmers are engaged in livestock production, which provides a maximum of $27.9 \%$ of total agricultural income to the IADA farmers (Table 9). Agricultural wages are another important source of agricultural income as $14.6 \%$ farmers are earning income by engaging themselves as labor in the IADA fields. Their wages, however, account for $2.1 \%$ of total agricultural income of all the surveyed farmers while an individual farmer's income from wage was found to be a maximum of $35.7 \%$ of his or her total agriculture related income.

Table 9: Farmers' Income from Different Agriculture Related Sources.

\begin{tabular}{lrrrrr}
\hline Income Range & $\begin{array}{r}\text { Paddy } \\
\text { Production }\end{array}$ & $\begin{array}{r}\text { Permanent } \\
\text { Plants for } \\
\text { Long Term }\end{array}$ & $\begin{array}{r}\text { Fruits and } \\
\text { Vegetables }\end{array}$ & $\begin{array}{r}\text { Livestock } \\
\text { Production }\end{array}$ & $\begin{array}{r}\text { Agricultural } \\
\text { Wage from } \\
\text { Labor Selling }\end{array}$ \\
\hline \hline $.01-10 \%$ & 0 & 20 & 6 & 10 & 12 \\
$10-20 \%$ & 0 & 17 & 0 & 2 & 11 \\
$20-30 \%$ & 1 & 12 & 0 & 1 & 3 \\
$30-40 \%$ & 1 & 10 & 0 & 0 & 3 \\
$40-50 \%$ & 3 & 3 & 0 & 0 & 0 \\
$50-60 \%$ & 4 & 2 & 0 & 0 & 0 \\
$60-70 \%$ & 13 & 2 & 0 & 0 & 0 \\
$70-80 \%$ & 17 & 0 & 0 & 0 & 0 \\
$80-90 \%$ & 26 & 0 & 0 & 0 & 0 \\
$90-100 \%$ & 133 & 0 & 0 & 0 & 0 \\
Total & 198 & 66 & 6 & 13 & 29 \\
$\%$ of Total & $100.0 \%$ & $33.3 \%$ & $3.0 \%$ & $6.6 \%$ & $14.6 \%$ \\
Maximum & $100.0 \%$ & $63.7 \%$ & $7.6 \%$ & $27.9 \%$ & $35.7 \%$ \\
Minimum & $23.5 \%$ & $0.0 \%$ & $0.0 \%$ & $0.0 \%$ & $0.0 \%$ \\
Proportion of Total Income & $90.3 \%$ & $7.0 \%$ & $0.1 \%$ & $0.5 \%$ & $2.1 \%$ \\
\hline
\end{tabular}

Impacts of Climate Changes on Food Security 
While the target of the IADA authorities is to ensure 7.5 tons of paddy production per hectare, the actual average yield found by the survey is 6.85 tons per hectare. The survey also found that among the people working in the IADA fields there were actually $67 \%$ farmers and that $51.8 \%$ areas of the IADA fields are being cultivated for paddy production, which are clearly below the government's target level. Paddy yield in the IADA area of West Selangor reported was 5.042 tons per hectare in 2007 while the yield decreased to 4.819 tons per hectare in $2008{ }^{\left[{ }^{[2]}\right.}$ Under such variation in yield due to climatic change, it seems to be very tough for the farmers to meet the yield target and the IADA authorities will also find it hard to attract farmers to produce paddy. In fact, climate change is proven to have a negative impact on food security, which coincides with the actual perception of agricultural farmers as evident in the present study. As many as $64.1 \%$ of all the surveyed farmers reported that yield of paddy production decreases due to climate change while a total of $65.2 \%$ of those farmers further reported the same impact for the other crops (Table 10). So it appears that continuous decreases in crop yield will negatively affect both the self-sufficiency and long-term food security of the country.

Table 10: Farmers Perception of Yield Changes for Paddy and Other Crops Due to Climate Change.

\begin{tabular}{|c|c|c|c|c|c|c|c|c|c|}
\hline \multirow{2}{*}{$\begin{array}{l}\text { Types of } \\
\text { Supports }\end{array}$} & \multicolumn{5}{|c|}{ Observation Scale* } & \multirow{2}{*}{$\begin{array}{l}\text { Average } \\
\text { Value of } \\
\text { Scale } \\
\end{array}$} & \multirow{2}{*}{ S.D. } & \multirow{2}{*}{$\begin{array}{c}\text { Agreed } \\
(4 \& 5) \\
\text { Observation }\end{array}$} & \multirow{2}{*}{$\begin{array}{c}\text { Disagreed } \\
(1 \& 2) \\
\text { Observation } \\
\end{array}$} \\
\hline & 1 & 2 & 3 & 4 & 5 & & & & \\
\hline $\begin{array}{l}\text { Yield of Paddy } \\
\text { Production Decreases }\end{array}$ & $\begin{array}{l}10 \\
5.1 \%\end{array}$ & $\begin{array}{c}13 \\
6.6 \%\end{array}$ & $\begin{array}{c}48 \\
24.2 \%\end{array}$ & $\begin{array}{c}42 \\
21.2 \%\end{array}$ & $\begin{array}{c}85 \\
42.9 \%\end{array}$ & 3.9 & 1.18 & $\begin{array}{c}127 \\
64.1 \%\end{array}$ & $\begin{array}{c}23 \\
11.6 \%\end{array}$ \\
\hline $\begin{array}{l}\text { Yield of Other Crops } \\
\text { Production Decreases }\end{array}$ & $\begin{array}{c}12 \\
6.1 \%\end{array}$ & $\begin{array}{c}8 \\
4 \%\end{array}$ & $\begin{array}{c}49 \\
24.7 \%\end{array}$ & $\begin{array}{c}77 \\
38.9 \%\end{array}$ & $\begin{array}{c}52 \\
26.3 \%\end{array}$ & 3.75 & 1.08 & $\begin{array}{c}129 \\
65.2 \%\end{array}$ & $\begin{array}{c}20 \\
10.1 \%\end{array}$ \\
\hline
\end{tabular}

*Scale: 1 = Strongly Disagree, 2 = Disagree, 3 = No Comment, 4 = Agree, 5 = Strongly Agree.

The survey conducted by the study further reveals that farmers' selection of crops also depends on historical record of different crops. As a matter of fact, $72.2 \%$ of all the surveyed farmers reported that they consider previous years' price and productivity rate of alternative crops to select one for planting (Table 11). The survey also reveals a remarkable finding that $7.1 \%$ of those farmers are not willing to produce paddy in next season. As a result, paddy planting area in the IADA fields tends to decrease over the next seasons. However, the average decrease of paddy land reported by the IADA Authorities for the last three years was 
$0.34 \%$ (Table 12). In spite of government's regulation and constant subsidy in the agriculture sector, every year the IADA's paddy planting area decreases and this trend continues.

Table 11: Crop Selection Decision of Farmers.

\begin{tabular}{|c|c|c|c|c|c|c|c|c|c|}
\hline \multirow{2}{*}{ Types of Supports } & \multicolumn{5}{|c|}{ Observation Scale* } & \multirow{2}{*}{$\begin{array}{c}\text { Average } \\
\text { Value of } \\
\text { Scale }\end{array}$} & \multirow{2}{*}{ S.D. } & \multirow{2}{*}{$\begin{array}{c}\text { Agreed } \\
(4 \& 5) \\
\text { Observation }\end{array}$} & \multirow{2}{*}{$\begin{array}{l}\text { Disagreed } \\
\quad(1 \& 2) \\
\text { Observation }\end{array}$} \\
\hline & 1 & 2 & 3 & 4 & 5 & & & & \\
\hline $\begin{array}{l}\text { Consider previous } \\
\text { years' price and } \\
\text { productivity rate of } \\
\text { different crops to } \\
\text { select one for } \\
\text { planting }\end{array}$ & $\begin{array}{c}3 \\
1.5 \%\end{array}$ & $\begin{array}{c}6 \\
3 \%\end{array}$ & $\begin{array}{c}46 \\
23.2 \%\end{array}$ & $\begin{array}{c}76 \\
38.4 \%\end{array}$ & $\begin{array}{c}67 \\
33.8 \%\end{array}$ & 4 & 0.91 & $\begin{array}{c}143 \\
72.2 \%\end{array}$ & $\begin{array}{c}9 \\
4.5 \%\end{array}$ \\
\hline $\begin{array}{l}\text { Wish to produce } \\
\text { paddy in next } \\
\text { season }\end{array}$ & $\begin{array}{c}2 \\
1 \%\end{array}$ & $\begin{array}{c}1 \\
0.5 \%\end{array}$ & $\begin{array}{c}11 \\
5.6 \%\end{array}$ & $\begin{array}{c}59 \\
29.8 \%\end{array}$ & $\begin{array}{c}125 \\
63.1 \%\end{array}$ & 4.54 & 0.72 & $\begin{array}{c}184 \\
92.9 \%\end{array}$ & $\begin{array}{c}3 \\
1.5 \%\end{array}$ \\
\hline
\end{tabular}

*Scale: 1 = Strongly Disagree, 2 = Disagree, 3 = No Comment, 4 = Agree, 5 = Strongly Agree

Table 12: Changes in Paddy Planting Area in IADA, West Selangor. ${ }^{[36]}$

\begin{tabular}{ccc}
\hline Year & $\begin{array}{c}\text { Paddy Planting Area } \\
\text { (In Hectares) }\end{array}$ & $\begin{array}{c}\text { Changing Rate of Paddy } \\
\text { Planting Area }\end{array}$ \\
\hline \hline 2005 & 18490 & \\
2006 & 18399 & $-0.49 \%$ \\
2007 & 18355 & $-0.24 \%$ \\
2008 & 18301 & $-0.29 \%$ \\
\hline
\end{tabular}

\section{POLICY RECOMMENDATION AND CONCLUSIONS}

As climate change is a continuous and long term process, its effects and solutions are similarly time and effort consuming process. Most of the warming during the next 30 years will be due to emissions that have already occurred. Over the longer term, the degree and pace of warming mainly depend on current and near future emissions. ${ }^{[37]}$ To adopt with climate change, conventionally, mitigation has received more attention than adaptation, both from a scientific and policy perspective. Mitigation is the main way to prevent future impacts of climate change, and it will reduce the cost of adaptation. So, any delay in mitigation strategy to reduce emissions will increase the need and cost of adaptation, and increase the risk of global climate change. On the other hand, though adaptation is not a substitute of mitigation, there are arguments for adaptation to consider as a response measure. Mitigation actions never stop a certain degree of climate change due to historical emissions and the inertia of the climate system. ${ }^{[38]}$ Moreover, mitigation effects may take several decades to manifest, where most adaptation activities take immediate effect. Adaptation reduces risks 
associated with current climate variability as well as addressing the risks associated with future climate changes, where mitigation only focuses on future risks. The measures of adaptation can be applied to a local scale or root level with the involvement of large number of stakeholders, where mitigation works in the decision making level. In the current world, climate factors are exogenous variables that are immitigable in a quick manner and as a consequence adaptation is the most appropriate way to cope the system properly. It is therefore important to balance between measures against the causes of climate change and measures to cope with its adverse effects. ${ }^{[37,39]}$

In recent years, adaptation has gained prominence as an essential response measure, especially for vulnerable countries due to the fact that some impacts are now unavoidable in the short to medium term. ${ }^{[40]}$ Mitigation is necessary but adapting to future risk is more important. Immediate and long term actions are essential for various actors including government, development partners, research organizations, and community organizations. In fact, adaptation is too broad to attribute its costs clearly, because it needs to be undertaken at many levels, including at the household and community level, and many of these initiatives are self-funded. ${ }^{[37]}$ Options for agricultural adaptation can be grouped as technological developments, government programs, farm production practices, and farm financial management. ${ }^{[41]}$ So, it has been suggested to prepare a planned and proactive adaptation strategy to secure sound functioning of the economic, social and environmental system. For the case of this study, however, relevant and specific policy recommendations have been proposed below for appropriate stakeholders for better copping up with the impacts of climate changes in the IADA area of Northwest Selangor, Malaysia. Depending on the degree to which current climate change impacts in the above area are similar to those in other IADA areas, states, regions, and countries the following policy recommendations will have wider applicability.

Government as the policy and law making authority has to play most influential role to ensure climatic mitigation and adaptation at all levels. It is the main responsibility of government to give enough supports in order to enable farmers to adapt to different climatic situations and to make them self sufficient rather than subsidy dependent. Appropriate authorities also need to carefully define government's subsidy supports and incentive programmes to influence farm-level production, practices, and financial management. Hence, agricultural policies and investments need to be more strategic. But the government needs to 
define and ensure the compensation, minimum income protection, and insurance facility for the affected groups - individual farmer or farm. In the planning processes, policy makers need to account the barriers of adaptation including ecological, financial, institutional, and technological barriers, as well as information and cognitive hurdles. Other few important issues need to be focused, such as stakeholders may not sufficiently inform about the needs and possible strategies of climate change ${ }^{[42-43]}$, farm level faces uncertain future and hinder the development process causes to obstacle for implementation of adaptations policy ${ }^{[44-45]}$, and the policy deals with different conflicting interest groups. To avoid the negative impacts of climate changes on agriculture and to control pollutions and emissions in the sector, however, proper mitigation policies are urgently required for Malaysia. Further, Malaysian agriculture sector also needs to include mitigation policies due to the emission of commercial farming.

The issues of mitigation and adaptation to climate change concern all sectors as well as all levels of political, administrative, economic and everyday life. To better cope up, cooperation is necessary across countries, sectors and administrative levels. Relevant actors are needed to be aware of the benefits of cooperation to gain long-term benefits instead of focusing only on short-term and individual interest. The production practices of farm and the knowledge of individual farmer also need to be updated with the changes of climate factors. The agricultural farmers should understand the crop rotation, crop portfolio, and crop substitutions. They should also take all precautions and be aware about the uncertainty of low rainfall and heavy rainfall. The financial management of agricultural farms must be efficient and the farmers must secure for minimum two cropping seasons so that if crops damage in one season they will have the seeds for next season. This will help them bear the cost of another crop production and survive financially up to the time when new crops are collected. But this will require the farmers take initiative for crop sharing, forward rating, hedging, and insurance etc.

On the basis of several requirements of farmers, however, the IADA authorities in Northwest Selangor also need to engage different new groups of stakeholders to ensure necessary facilities for the farmers. They also need to engage financial institutions more inclusively in order to provide supports of loan, insurance, saving schemes, hedging or future option, and so on to the agricultural farmers. Technological adaptation to climate change is also important to deal with the climatic problems in the long run. It is apparent that 
development of technology is a boundless area, but it is possible in several ways. The highest efficient method of technological advancement is expected to be able to solve the problem. Until gaining such level of technological advancement, there should be some alternative options which are expected to help the agricultural farmers in their effort to adapt to climate changes in the following ways:

- To solve the problem: controlling the pattern of rainfall, sunshine, and moisture level.

- To improve shielding resources: protecting crops from excessive rainfall or sunshine and solving water login problems.

- To develop defensive approach: development of verities of crops, development of rainfall and temperature tolerant plants, and finding alternative crops and hybrids.

- To find alternative approach: changing crop cycle and reducing the timing of crop cycle.

- To provide information: providing weather forecast and early warning system and ensuring delivery of proper information at the farm level.

The impacts of climate change on agricultural sustainability vary from country to country, region to region and time to time. The yield and productivity of agricultural crops in Malaysia are proven to have been heavily influenced by climatic variations. Malaysia is the $26^{\text {th }}$ largest greenhouse gas emitter which causes the expected rise of temperature by $0.3^{\circ} \mathrm{C}$ to $4.5^{\circ} \mathrm{C}$, and rise in sea level is expected to be about $95 \mathrm{~cm}$ over a hundred years. The changes in the country's rainfall fluctuate heavily from $-30 \%$ to $+30 \%$. This change reduces crop yield and is prone to drought in many areas so that cultivation of some crops such as rubber, oil palm and cocoa becomes unfeasible. Current crop productivity is also affected by the climatic variations throughout the country as the actual farm yields of rice in Malaysia vary from 3-5 tons per hectare while the potential yield is 7.2 tons per hectare. The projection of climate change and its impacts on productivity and farmers' profitability are thus considered as very alarming.

\section{ACKNOWLEDGEMENT}


We are thankful to Ministry of Science, Technology and Environment of the Government of Malaysia for generously funding the research, under the Research University Grant (UKMGUP-PI-08-34-081). We would also like to thank Prof. Dr. Rafiqul Islam Molla (Multimedia University, Malaysia) and Dr. Basri Talib (National University of Malaysia) for their advices and supports at various stages of the study.

\section{REFERENCES}

1. Warren, R., N. Arnell, R. Nicholls, P. Levy and J. Price, 2006. Understanding the regional impacts of climate change. Research report prepared for the Stern Review, Tyndall Centre Working Paper 90, Tyndall Centre, Norwich.

2. Parry, M.L., C. Rosenzweig, A. Iglesias, G. Fischer and M.T.J. Livermore, 2004. Effects of climate change on global food production under SRES emissions and socio-economic scenarios. Global Environmental Change, 14: 53-67.

3. FAO, 2008. High-Level Conference on World Food Security: The Challenges of Climate Change and Bioenergy: Soaring Food Prices: Facts, Perspectives, Impacts and Actions Required. Food and Agriculture Organization of the United Nations, Rome.

4. Boko, M., I. Niang, A. Nyong, C. Vogel, A. Githeko, M. Medany, B. OsmanElasha, R. Tabo and P. Yanda, 2007. 'Africa' in climate change 2007: impacts, adaptation and vulnerability. In Parry, M.L., O.F. Canziani, J.P. Palutikof, P.J. Van der Linden and C.E. Hanson (eds.). Contribution of Working Group II to the Fourth Assessment Report of the Intergovernmental Panel on Climate Change. Cambridge University Press, Cambridge UK.

5. Lobell, D.B., M.B. Burke, C. Tebaldi, M.D. Mastrandrea, W.P. Falcon and R.L. Naylor, 2008. Prioritizing climate change adaptation needs for food security in 2030. Science, 319(5863): 607-610.

6. Matthews, R.B., M.J. Kropff, D. Bachelet, H.H. van Laar, 1994a. Climate Change and Rice Production in Asia. Entwicklung und Landlicherraum, 1: 16-19.

7. Matthews, R.B., M.J. Kropff, D. Bachelet, H.H. van Laar, 1994b. The Impact of Global Climate Change on Rice Production in Asia: a Simulation Study. Report No. ERL-COR-821. Corvallis, OR: U.S. Environmental Protection Agency, Environmental Research Laboratory.

8. MOSTE, 2001. National Response Strategies to Climate Change. Ministry of Science, Technology and the Environment, Putrajaya, Malaysia.

9. Tashiro, T. and I.F Wardlaw, 1989. A comparison of the effect of high temperature on grain development in wheat and rice. Annals of Botany, 64: 59-65.

10. Baker, J.T. and Jr.L.H. Allen, 1993. Contrasting crop species responses to $\mathrm{CO}_{2}$ and temperature: rice, soybean and citrus. Vegetatio, 104/105: 239-260.

11. Singh, S., R. Amartalingam, W.S. Wan Harun, and .T. Islam, 1996. Simulated impact of climate change on rice production in Peninsular Malaysia. Proceeding of National Conference on Climate Change. pp. 41-49, UPM, Malaysia.

12. Ali, R. and A.K. Ali, 2009. Estimating the Prospective Impacts of Global Warming on Malaysian Agriculture. Proceeding of 2nd National Conference on AgroEnvironment 2009, MARDI, Malaysia, Mar 24-26. 
13. Alam, M.M., B. Talib, C. Siwar and T. Mohd Ekhwan, 2010a. The Impacts of Climate Change on Paddy Production in Malaysia: Case of Paddy Farming in North-West Selangor. Proceedings of the international conference of the 4th International Malaysia-Thailand Conference on South Asian Studies. National University of Malaysia, Malaysia, Mar 25-26.

14. The Associated Press, 2007. Malaysian Growth of Carbon Emissions Highest in the World, UN Says. The Irrawaddy. Nov 29. (Online) http://www.irrawaddy.org/article.php?art_id=9454 (Oct 1 2009).

15. Liebman, B., 2007. Malaysia leads the world in greenhouse gas emission growth rate. Curb Global Warming. Nov 29. (Online) http://curbglobalwarmingblog.blogspot.com/2007/11/malaysia-leads-world-ingreenhouse-gas.html (Oct 1 2010).

16. NAHRIM, 2006. Final Report: Study of the Impact of Climate Change on the hydrologic Regime and Water Resources of Peninsular Malaysia, National Hydraulic Research Institute of Malaysia (NAHRIM) and California Hydrologic Research Laboratory (CHRL), Malaysia.

17. Tisdell, C., 1996. Economic indicators to assess the sustainability of conservation farming projects: An evaluation. Agriculture, Ecosystems and Environment, 57(2): 117-131.

18. Alam, M.M., T. Mohd Ekhwan, C. Siwar and B. Talib, 2011a. Rainfall variation and changing pattern of agricultural cycle. American Journal of Environmental Science, 7: 82-89. DOI 10.3844/ajessp.2011.82.89 (Cited 05 Aug 2011)

19. Malaysia, 1986. Fifth Malaysia Plan, 1986-1990. Kuala Lumpur: National Printing Malaysia Berhad.

20. Malaysia, 1991. Sixth Malaysia Plan, 1991-1995. Kuala Lumpur: National Printing Malaysia Berhad.

21. Malaysia, 1996. Seventh Malaysia Plan, 1996-2000. Kuala Lumpur: National Printing Malaysia Berhad.

22. Malaysia, 2001. Eighth Malaysia Plan, 2001-2005. Kuala Lumpur: National Printing Malaysia Berhad.

23. Malaysia, 2006. Ninth Malaysia Plan, 2006-2010, Economic Planning Unit, Prime Minister's Department, Putrajaya.

24. Arshad, F.M., M.N. Shamsudin and R. Saleh, 1999. Food Security in Malaysia, Presented at Seminar on International Trade and Food Security. Asian Productivity Organisation, Tokyo, February.

25. Agriculture Statistical Handbook, 2008. Paddy. Ministry of agriculture. Malaysia.

26. Selvadurai, S., 1972. Padi Production in West Malaysia. Ministry of Agriculture, Malaysia.

27. Arshad, F.M., 2007. Agriculture Development Path in Malaysia. In Arshad, F.M., N.M.R. Abdullah, B. Kaur, and A.M. Abdullah. 50 Years of Malaysian Agriculture: Transformational Issues Challenges \& Direction. 3-46. Universiti Putra Malaysia, Serdang.

28. Alam, M.M., C. Siwar and T. Mohd Ekhwan, 2010b. Socioeconomic Study of Climate Change: An Assessment of Agriculture and Livelihood Sustainability on Paddy Farming in Malaysia. LAP Lambert Academic Publishing, Saarbrucken.

29. Alam, M.M., C. Siwar, R.I. Molla, T. Mohd Ekhwan and B. Talib, 2010c. Socioeconomic Impacts of Climatic Change on Paddy Cultivation: An Empirical Investigation in Malaysia. Journal of Knowledge Globalization, 3(2): 71-84. (Online) http://journals.sfu.ca/jkg/index.php/journal/article/view/57/44 (Cited 05 Aug 2011). 
30. Alam, M.M., C. Siwar, M.W. Murad, R.I. Molla and T. Mohd Ekhwan, 2010d. Socioeconomic Profile of Farmer in Malaysia: Study on Integrated Agricultural Development Area in North-West Selangor. Agricultural Economics and Rural Development, 7(2): 249-26. (Online) ftp://www.ipe.ro/RePEc/iag/iag_pdf/AERD1013_249-265.pdf (Cited 05 Aug 2011).

31. Siwar C, M.M. Alam, M.W. Murad and A.Q. Al-amin, 2009. A review of the linkages between climate change, agricultural sustainability and poverty in Malaysia. International Review of Business Research Papers, 5(6):309-321. (Online) http://www.bizresearchpapers.com/23.\%20Siwar.pdf. Cited 05 Aug 2011

32. Alam, M.M., C. Siwar and A.Q. Al-Amin, 2010e. Climate Change Adaptation Policy Guidelines for Agricultural Sector in Malaysia. Asian Journal of Environmental and Disaster Management, 2(4): 463-469. DOI 10.3850/S1793924011000873 (Cited 05 Aug 2011).

33. Alam, M.M., C. Siwar, B. Talib and T. Mohd Ekhwan, 2011b. An Empirical Study on the Relationships between the Socioeconomic Profile of Farmers and Paddy Productivity in North-West Selangor, Malaysia. Asia-Pacific Development Journal, 18(1). (Online) http://www.unescap.org/pdd/publications/index_apdj.asp (Cited 05 Aug 2011).

34. Alam, M.M., T. Mohd Ekhwan, C. Siwar, R.I. Molla and B. Talib, 2011c. The Impacts of Agricultural Supports for Climate Change Adaptation: Farm Level Assessment Study on Paddy Farmers. American Journal of Environmental Sciences, 7(2): 178-182. DOI 10.3844/ajessp.2011.82.89 (Cited 05 Aug 2011).

35. Alam, M.M., C. Siwar, T. Mohd Ekhwan, R.I. Molla and B. Talib, 2011d. Climate Change Induced Adaptation by Paddy Farmers in Malaysia, Mitigation and Adaptation for Global Change, 16(7), DOI: 10.1007/s11027-011-9319-5 (Cited 05 Aug 2011).

36. IADA (Integrated Agricultural Development Area), 2009. Internal Unpublished Data from the record of North West Selangor, Malaysia, March.

37. Stern, N., 2007. The Economics of Climate Change: The Stern Review. Cambridge University Press, Cambridge.

38. IPCC (Intergovernmental Panel on Climate Change), 2001. Climate Change 2001: Impacts, Adaptation and Vulnerability. IPCC Third Assessment Report, Cambridge University Press, Cambridge, U.K.

39. Pielke, R., G. Prins, S. Rayner and D. Sarewitz, 2007. Lifting the taboo on adaptation. Nature, 445(7128): 597-598.

40. Alam, M.M., C. Siwar, R.I. Molla, T. Mohd Ekhwan and B. Talib, 2011e. Climate Change and Vulnerability of Paddy Cultivation in North-West Selangor, Malaysia: A Survey of Farmers' Assessment. Voice of Academia, 6(1):45-56.

41. Smit, B. and M.W. Skinner, 2002. Adaptation options in agriculture to climate change: a typology. Mitigation and Adaptation Strategies for Global Change, 7: 85114.

42. Eisenack, K. and J. Kropp, 2006. Regional stakeholder perceptions of climate change: Baltic case study screening, ASTRA document, Potsdam.

43. Eisenack, K., V. Tekken and J. Kropp, 2007. Stakeholder Perceptions of climate change in the Baltic Sea Region. Coastline Reports, 8: 245-255.

44. Behringer, J., R. Buerki and J. Fuhrer, 2000. Participatory integrated assessment of adaptation to climate change in Alpine tourism and mountain agriculture. Integrated Assessment, 1: 331-338. 
45. Brown, K., R. Few and E.L. Tompkins, 2007. Climate change and coastal management decisions: insights from Christchurch Bay, Coastal Management, 35(2-3): 255-270. 